\title{
Scientific Literacy: The Conceptual Framework Prevailing over the First Decade of the Twenty-First Century
}

Alfabetización científica: el marco

conceptual que prevalece en la primera década del siglo XXI

Literacia científica: enquadramento conceptual que prevalece na primeira década do século XXI

António Manuel Costa* iD orcid.org/0000-0003-3316-5605

Maria Eduarda Ferreira** iD orcid.org/0000-0003-1010-4404

Manuel Joaquim da Silva Loureiro*** (iD orcid.org/0000-0003-1010-4404

Para citar este artículo: Costa, A., Ferreira, M. y da Silva, M. (2O21). Scientific Literacy: The Conceptual Framework Prevailing over the First Decade of the Twenty-First Century. Revista Colombiana de Educación l(81), 195-228. https://doi.org/10.17227/rce.num81-10293

\section{(c) $(1)(9)$}

Recibido: 16/07/2019

Evaluado: 11/05/2020

* Doutorado em Educacion. Escola Regional Dr. José Dinis da Fonseca, Portugal, Research Unit for Inland Development, Polytechnic Institute of Guarda, Portugal. Correo: antoniocosta@ipg.pt

** Doutorado em Biologia, Agregação em Educação. Escola Superior de Educação, Comunicação e Desporto, CI\&DEI, Instituto Politécnico da Guarda, Portugal. Correo: eroque@ipg.pt

*** Doutorado em Psicologia com Agregação em Psicologia. Professor do Departamento de Psicologia e Educação da Universidade da Beira Interior (Covilhã, Portugal), Research Center in Sports Sciences, Health Sciences and Human Development (CIDESD). Correo: loureiro@ubi.pt 


\begin{abstract}
The term scientific literacy arises due to the need of the scientific community to see that the population validated its scientific and technological production. The construct Scientific literacy has been subject to diverse conceptual considerations over the years, arising from the scientific, technological, social and political changes that marked contemporary society characteristics. In this study, we sought to assess the evolution of the scientific literacy construct over the first decade of the twenty-first century, through qualitative research, using a bibliographic study. For the operationalization of this analysis, different dimensions for scientific literacy were defined. The results suggest that scientific literacy embodies a construct that is deictic in nature, shaped by the social, political, cultural and scientific contexts prevailing in the society it belongs to. The conclusion is that all of this conceptual matrix suggests a change in the relatively passive form in which science is appreciated of and the way this operates in society towards a commitment to personal involvement with science and towards the valuation of the importance of scientific knowledge throughout life.
\end{abstract}

\section{Keywords}

scientific literacy; bibliographic study; science and society; qualitative research; social environment

\section{Palabras clave}

alfabetización científica; estudio bibliográfico; ciencia

y sociedad; investigación cualitativa; entorno social

\section{Resumen}

El término alfabetización científica surge como consecuencia de la necesidad de la comunidad científica de ver validada, por parte de la población, la producción científica y tecnológica. El constructo alfabetización científica fue objeto de varias actualizaciones conceptuales a lo largo de los años como resultado de los cambios científicos, tecnológicos y sociales de la sociedad contemporánea. En esta investigación se realiza una revisión sistemática en la cual se analiza la evolución de la alfabetización científica en la primera década de este siglo. Buscamos evaluar la evolución del constructo alfabetización científica durante la primera década del siglo XXI, a través de una investigación cualitativa, realizando un estudio bibliográfico. Para la operacionalización de este análisis, se definieron diferentes dimensiones de la alfabetización científica. Los resultados indican que es un constructo de naturaleza deíctica, que conforma su contenido a los entornos social, político, cultural y científico en que se inserta. La conclusión es que toda esta matriz conceptual sugiere un cambio en la forma relativamente pasiva como se aprecia la ciencia y como esta funciona en la sociedad hacia un compromiso de implicación personal con la ciencia y hacia la valoración de la utilidad del conocimiento científico a lo largo de la vida.

\section{Resumo}

O termo literacia científica surge em consequência da necessidade da comunidade científica ver validada, por parte da população, a produção científica e tecnológica da época. Literacia científica representa um construto sujeito a diversas representações conceituais ao longo dos anos decorrentes das modificações científicas, tecnológicas, sociais e políticas características da sociedade contemporânea. Neste estudo, procurou-se aferir a evolução do construto literacia científica ao longo da primeira década do século xxi, através da análise qualitativa, com recurso à revisão da literatura. Para a operacionalização desta análise foram definidas diferentes dimensões para a literacia científica. Os resultados obtidos mostram como a literacia científica incorpora um constructo de caráter dêitico que molda o conteúdo ao contexto social, político, cultural e científico que prevalece na respectiva sociedade. Conclui-se que toda essa matriz conceitual sugere uma mudança na forma relativamente passiva de valorização da ciência e no modo como esta opera na sociedade em direção ao compromisso com o envolvimento pessoal com a ciência e à valorização da utilidade do conhecimento científico ao longo da vida.

\section{Palavras-chave}

literacia científica; revisão da literatura; ciência e sociedade, investigação qualitativa; enquadramento social 


\section{Introduction}

Each generation, in their own respective timeframe, endows a different form on the aspirations that shape their society with that identifying those of the current generation involving the renovation of generalised concerns over the social, political and cultural quality of life of populations. In order to achieve this goal, each generation draws upon science and technology (s\&T) as an instrument for fostering social justice. To obtain the desired goals, there is a need to provide citizens with the tools to develop their s\&T competences and knowledge. These tools need to be designed, implemented and developed within the field of Science Education (SE) and seek to develop individual Scientific Literacy (SL) not only as an intellectual capacity but also as the attitudinal, social and interdisciplinary attributes (Holbrook \& Rannikmae, 2009) that enable socially active beings.

This research started from these two attributes-intellectual and social - and the analyses ot the evolution of the sL construct over the last decade of the twentieth century. Then, we undertook a systematic review of the literature on the st construct over the temporal frame set by the first decade of this century.

\section{Historical evolution}

The presence of science on school curriculums dates back to the nineteenth century, due, among other reasons, to the pressures applied by scientists of this period, including Thomas Huxley, Herbert Spencer, Charles Lyell and Michael Faraday, concerning the need for the teaching of science (Deboer, 1991). At that time, this advocacy of science teaching in schools encountered strong opposition from people in the Humanities field. Hence, each scientist had to take a proactive attitude in arguing for the utility of science and dispelling the vision of science as a materialistic activity lacking any virtue (Deboer, 2000). The promotion of science teaching in schools grew alongside the need to endow citizens with independent scientific thinking as a means of broadening and deepening the efficient participation of citizens in their societies. This need to produce independent thinking is one of the objectives of education, for if a student does not put into practice the acquired skills or does not use them for productive purposes, then education has failed to reach its primary objective (Deboer, 2000).

While still displaying some concerns about the high level of relevance that school curricula attributed to the role of science, very often forgetting that the fundamental purpose of science is knowledge about the 
natural world and its impact on the personal and social lives of citizens. This concern prevailed during the inter-war period (Choi et al., 2011; Murcia, 2009; Roth \& Lee, 2001; van Eijck \& Roth, 2010).

In the period following World War Two, the role of science and technology grew exponentially in society stemming from the increase in citizen's participation in scientific and technological issues (Irwin \& Michael, 2003). This involvement evolved in very differentiated ways according to the time frameworks, which has led to many authors framing the impact of science on diverse dimensions of society into three distinct periods: a) between the end of World War Two and the late 1950s; b) the beginning of the 1960s; c) the beginning of the 1980s (Miller \& Pardo, 2003).

Deepening this perspective, Miller \& Pardo (2003) state that following the conclusion of World War Two, the work undertaken by engineers and scientists gained recognition and value due to the rise in the standard of living. Thus, the diverse practical applications, including highlights such as the production of new medications, new planes emerging in the aeronautics, the pesticides and the progress in communications, ended up reaching an increasing number of individuals, which brought about the greater valuation of scientific and technological knowledge (Bauer et al., 2003).

Advancing with this historical outline, the second phase began in the 1960s with the publication of a series of books defending the participation of society in decision-making around s\&T related issues. These publications advocated the need to reduce the gap between citizens and scientists, so that individuals become socially participative (Deboer, 2000). This idea of greater civic participation derived primarily from the utilisation of different technological applications, which later proved harmful to society, especially to nature. This raised doubts about the positive influence of science and technology in the vanguard of social development and wellbeing, and regarding the role each citizen should play in the definition of the borders to that same s\&т (Deboer, 2000; Miller, 2004). Despite this desire for civic participation, various governments, scientific and technological organisations and the scientific community as a whole failed to duly recognise the scientific and technological competences of citizens for the definition of lines of research. Only at the beginning of the 1980s, as Miller \& Pardo (2003) identify, and coinciding with the third stage, there was some recognition by a significant proportion of the political and scientific community about the fact that citizens might be able to veto scientific projects. This third stage displays a greater level of scientific information among citizens due to the exponential increase in scientific-based communication, which 
reflected in consequences such as the rise in the speed and quantity of public debates on S\&T-related issues. In the same direction, various authors defend that the exponential growth in the number of debates on scientific and technological issues, as well as their visibility, implies a higher level of sL among citizens (Irwin \& Michael, 2003; Miller, 2004; Miller \& Pardo, 2003; Murcia, 2009; Norris \& Phillips, 2003).

\section{Nature of the concept}

The term scientific literacy has appeared in the literature over the last four decades (Deboer, 2000; Hurd, 1998), even if very often with varying interpretations and meanings (Deboer, 2000; Miller \& Pardo, 2003; Murcia, 2009; Osborne, 2007). This myriad of concepts, definitions and paths produced under the auspices of defining SL reflects in the growing importance of the $S \& T$ knowledge that a citizen should possessto have an active involvement in markedly scientific societies (Yuenyong \& Narjaikaew, 2009).

The information reaching the individuals, in different ways and across different communication platforms, should be processed and assimilated so that it may be applied subsequently in active participation in society (Choi et al., 2011; Hofstein et al., 2011; van Eijck \& Roth, 2010). This idea involved developing a collective cognitive potential, enabling a citizen to grasp reality, endowing this with a valid meaning for life and thus become more effective in terms of material actions on society (Caraça, 2001). As such, individual civic participation in the social collective should be leveraged by a socio-scientific matrix (Hofstein et al., 2011) so that, more than simply possessing a basic set of scientific knowledge, citizens should also have a clear vision as to how such knowledge interrelates with other events in society, the reasons why they are important and what vision of the world we may gain from them (Osborne, 2007). This formulation falls within the scope of the feasible dimensions that the literature defends for scientifically literate citizens (Bybee et al., 2009; Hofstein et al., 2011; Osborne, 2007). At the end of the last century some authors approached SL as holding four dimensions (Boujaoude, 2002; Hurd, 1998; Miller, 1998): (a) scientific knowledge; (b) research on the nature of science; (c) science as a form of thinking; (d) interactions with science, technology and society.

In addition to this interpretation, Hurd (1998) added other dimensions to the definition of SL to establish a denser construct in which the interactions between the triade science-technology-society emerges as the core and unavoidable marker of the definition of sL (Figure 1). 




Figure 1. Dimensions of scientific literacy. Adapted from Hurd (1998).

Even while sL is essential to participating in society, it does not emerge spontaneously in citizens, and there is a need for a continuum of understanding about the nature and the construction of the world. Bybee defines the acquisition of knowledge by levels beginning with a scientifically illiterate citizen, passing through nominal, functional, conceptual, processual and finally multidimensional literacy (Bybee, 1997). Furthermore, Bybee defends the existence of a minimum level of SL that runs across the population and accompanying citizens during their lifetime (Table 1). This level of literacy may experience alterations depending on the context or the theme in which the citizen is called upon to participate (Bybee, 1997; Laugksch, 2000; Osborne et al., 2003).

Defining the minimum level in which a citizen might be considered scientifically literate spans three dimensions: knowledge about science, the nature of science, and the interactions between science and society. Even after having defined these dimensions, this process did not gain any consensus. Therefore, to ensure greater clarity, the dimensions were expanded and indicators were established (Table 1). Analysis of Table 1 shows how we may approach SL as a sequential and hierarchical model that begins with ideas about science, moves on through knowledge about the nature of science, and ends with the interactions between s\&T and society. 
Table 1.

Levels of Scientific Literacy

\begin{tabular}{lll}
\hline \multicolumn{1}{c}{ Level } & \multicolumn{1}{c}{ Description } & \multicolumn{1}{c}{ Indicator of dimension } \\
\hline No Scientific & At this level, the citizen does not have the & \\
Literacy and & scientific capacity to understand science \\
Technology & $\begin{array}{l}\text { questions or to ast a question within a } \\
\text { specific scientific field. (Bybee, 1997). }\end{array}$ \\
\hline
\end{tabular}

This level, which Bybee called nominal SL, is illustrated by a person who recognizes when a term, question or topic is scientific in its nature, but, even so, demonstrates clear misunderstanding. The individual

Nominal understands the theme, the question or

Scientific Literacy topic as scientific, but exhibits an erroneous and Technology knowledge about the scientific field. The citizen may express naive explanations about such phenomena. An individual's understanding is minimal when compared to the accepted scientific understanding for the individual's age and situation. (Bybee, 1997).

At this level a person is able to use scientific and technological vocabulary in a particular

Functional activity when needed (e.g. defining terms in Scientific Literacy a test, reading a newspaper, or listening to a and Technology television program), but it is generally out of context and lacks the conceptual elaboration of disciplines. (Osborne \& Dillon, 2008).

The third level, conceptual and procedural
SL, describes people who understand the way conceptual parts of a discipline relate to the whole and how scientific disciplines

Conceptual and Processual relate to each other. They possess procedura Scientific Literacy skills, technological skills, ability to make and Technology

observations and hypotheses, developing new knowledge using evidence, logic and creativity). It can be described as the level of scientific ability which allows for solving practical problems. (Wolfensberger et al., 2010)

The highest level, multi-dimensional SL, illustrates whose understanding of science extends beyond the concepts of scientific disciplines and procedures of scientific investigation. More specifically, such

Multidimensional Scientific Literacy and Technology

subjects are able to make connections within

scientific disciplines, and among science, technology, and the larger issues challenging society. In other words, science education has promoted a broader view of science, while simultaneously helping foster an appreciation for science and its usefulness to society. (Holbrook \& Rannikmae, 2009).
The individual..

identifies the terms and questions as scientific.

demonstrates alternative conceptions

presents minimalist knowledge.

expresses naive

explanations.

The person...

uses scientific terminology. defines the terms correctly.

memorises specific concepts.

understands only an activity or specific need.

These people

Understand the conceptual scheme of science.

understand science-based competences.

understands the relationship between the parts and the whole of science.

understand the processes and principles of science.

These people

understand the role of science in the relationship with other fields of knowledge.

knows about the history of science.

knows about the nature of science.

understands the interactions between science and society. 
In Table 1, Functional Scientific Literacy and Technology places the focus on isolated scientific knowledge/ideas. Reaching that level involves establishing connections within such knowledge and understanding its production processes.

The highest level of $\mathrm{SL}$ requires an understanding of the interactions between science and society. It includes the history, objectives and general limitations of science. In this line of thought, sL enables the creative use of sound scientific knowledge in everyday life or in a career, to solve problems, make decisions and hence improve quality of life (Holbrook \& Rannikmae, 2009). In this view, st is important for both personal and professional life. It also highlights that, besides developing problem solving skills, enhancing SL also helps subjects improve their lives. In other words, it is associated with the capability to transfer knowledge, skills, attitudes and values to unknow situations such as showing initiative, thinking critically or reasoning onseself in a collaborative working situation.

Stemming from the establishment of these levels, in the early twenty-first century the interpretation of the definition of SL was characterised by the following set of factors (Figure 2): st interest groups; different purposes for advocating the promotion of $\mathrm{SL}$; different conceptual definitions of the term; different means of measurement; the relative or absolute nature of literacy (Laugksch, 2000; Miller, 1998).



Figure 2. Conceptual vision of SL in the early 21st century. Adapted from Laugksch (2000)

\section{Objectives and research questions}

The work of science is complex: it is a process, a product, and a institution. As a result, to engage in science-whether using knowledge or creating it - some familiarity with the enterprise and practice of science is needed. Knowledge of basic science facts is but one small part of the constellation of features that can constitute SL. 
All the dimensions and/or levels mentioned suggest that a scientifically literate individual needs not only to display an intellectual capacity, but also other attributes —attitudinal; social and interdisciplinary - in order to grasp and actively intervene in his or her own surroundings (Holbrook \& Rannikmae, 2009).

This research starts with these two attributes -intellectual and social- The objective is to analyse the evaluation of the SL construct over the first decade of the twenty-first century. For that purpose, we tried to answer the following three research questions:

What paradigm defined the sı existing in the early twenty-first century?

-How did this construct evolve over the course of the first decade of the twenty-first century?

What model of sL characterises the relationship between science and society?

\section{Methodology}

\section{Theoretical approach}

In order to answerthese questions, we carried out a systematic review of the literature on the $s L$ construct, taking as the time frame the first decade in the twenty-first century. The remarkable and rapid advances in science, technology, and engineering during that period have brought about unexampled changes in the quality of human life. These breakthroughs have united the world in unique ways and have dealt with the economic, societal, and political development (Friedman, 2007). The advances in science, technology, and engineering gave rise to a myriad of ethical, moral, and global issues that threaten human dignity and survival. To respond to these new challenges, society needs to prepare citizens who are able to understand scientific ideas, intellectual skills, creativity, and reasoning, as well as to raise in citizens awareness and respect for the issues and problems of the world. Thus, understanding the concept of SL in its different dimensions will allow us to discover which lines of thought prevailed during the beginning of the century and the extent to which they have allowed citizens to develop a scientific approach literacy that empowers them to make important decisions about the environment, health, and social policy for themselves, and the global community.

This research methodology was applied across three distinct levels, seeking to reduce the corpus of analysis to 250 articles (Figure 3). The first level involved the selection of the articles applying the $s L$ construct. At the second level, we codified the entries that fell within the scope of the 
different definitions associated with the concept of SL. This codification involved the use of $\mathrm{NVivo}^{\circledR}$ software. Finally, during the third level we caried out a sociological analysis of the articles.

Adopting the Web of Knowledge ${ }^{\circledR}$ and the whole range of articles published on this topic, we selected a sample of the 250 most cited articles during the research period. The article selection process encompassed all of the databases included in the Web of Science ${ }^{\circledast}$ collection. We entered the $S L$ construct and restricted the time frame to between 2000 and 2010. This search produced a total of 3,013 entries.

We tried to figure out whether the definition of scientific literacy accompanied the transition to a new millennium, to technology society, to a new world characterized by big social changes. We tried to understand if, during this transition, the definition of st followed all these social changes. For the selection of the sample we performed a non-probabilistic sampling with the technique of sampling by rational choice, where individual elements are selected according to the typical characteristics (Freixo, 2010). Out of the universe of 3,013 entries, we calculated the sample $(n=250)$ using a margin of error of $-5.0 \%$; and a confidence level of $-90 \%$. For this research, we only took into account documents dealing with empirical studies, and did not consider any documents refering to local, regional or international public policies for the review, analysis or promotion of st. The definition of the state of art of any construct seeks to portray the lines of thinking that the scientific community most commonly applies to its characterisation. Additionally, we analysed the trends in ideas, thinking and the definitions that accompany the construct. To this end, the selection of the most cited articles about a particular construct generates a perception and analysis of the path that the scientific community is setting out for the construct being under analysis.



Figure 3. Article selection stages.

Source: Own elaboration. 


\section{Codification of the different definitions of scientific literacy}

After the selection of the samples, we did a systematic review of the literature for the SL construct. The objective was to analyse all articles $(n=250)$ looking for lines of thought that accommodated answers for the research questions. To carry out this review, by using $\mathrm{Nvivo}^{\circledR}$ software, we identified the following six dimensions used to characterise the concept of SL in the early twenty-first century: (a) capacity to distinguish between science and non-science; (b) understanding science and its applications; (c) capacity to apply scientific knowledge for problem solving; (d) understanding the nature of science, including its relationship with culture; (e) Appreciation and comfort with Science, including admiration and curiosity; (f) understanding and appreciating s\&T and its interrelationship with society (Hurd, 1998; Laugksch, 2000; Norris \& Phillips, 2003).

The authors coded automatically each of the six dimensions, and counted the number of sources and the number of references (Table 1). After the codification of the different expressions, only 134 sources out of the initial 250 were identified, $53.6 \%$ of the initial articles. This difference can be explained because the initial research has only the sL construct that can be applied in different situations. When the search is refined, looking for the different dimensions of the concept itself, the specificity of the document increases and, consequently, the number of sources decreases.

The articles were read for each dimension of the scientific literature and taken as a framework of ideas and critical references (Table 2). The search for authors' guidelines and purposes is the best way to develop st in this time frame.

\section{Sociological analysis}

Although only 134 sources have been found with references to the dimensions encoded, we carried out a sociological analysis of the total sample (no. $=250$ ). The analysis criteria were: (a) article language; (b) number of authors per article, (c) affiliation(s) of the article author(s), (d) journal publishing the article, and (e) the country of journal publication. The results and their own analysis are presented in the following section. 


\section{Results}

\section{Sociological analysis}

\section{Author affiliations}

Analysis of these articles account for $97 \%$ (no. = 243) written in English, contrasting with only $3 \%($ no. $=7)$ in other languages, such as Portuguese and Spanish. These results are in keeping with the predominance of the English language in scientific outputs published worldwide. Even while writing in English appears universal, these studies' authors came mostly from the northern hemisphere and from countries with high levels of development (Figure 4). Data highlight North America as the global region which produces the most of cited works, with $47 \%(n=114)$ of the authors associated to works on SL. At the opposite end, Africa shows the lowest number of cited works $<0.01 \%($ no. $=2)$. This low result does not come as a surprise. The Academic Ranking of World Universities classifies the world's universities on the grounds of six objective indicators, which include the number of alumni and staff winning Nobel prizes and Fields medals, number of highly-cited researchers selected by Clarivate Analytics, number of articles published in Nature and Science journals, number of articles included in the Science Citation Index- Expanded and the Social Sciences Citation Index, and per capita performance of a university. Looking at this ranking since 2004 -the year in which data for regions of the globe began-, and 2010, you can see that only an average of four African universities out of the first 500 worldwide were in this ranking. This fact clearly illustrates the scarce scientific production carried out in this continent, as reflected in the low affiliation of researchers to universities in the African continent.



Graph 1. Affiliations of article authors. 
According to the results, the number of South American authors is almost half of European authors. This total stems primarily from Brazil's strong contribution. On the other hand, in terms of author affiliations, 9.6\% (no. $=24$ ) of the articles published are the result of international partnerships that feature collaborations between highly developed countries, such as Australia and Germany; the United States and Canada; the United States and Israel, and the United States, Canada and Australia.

\section{Number of authors per article}

Most papers are collaborations among partners from the same country, with a particular emphasis on those from the United States. Although the most common number of authors per article is 1 (mode $=1$ ), accounting for $37.6 \%$ (no. =94) out of the total, we also observe a significant number of articles written by pairs of authors, adding a total of $30.4 \%$ (no. = 76), or with three colleagues, $21.6 \%($ no. = 54) (Figure 5). However, there is but a small and practically residual number of articles by five authors, just $4.5 \%$ (no. = 13). The prevalence of smaller research groups may stem from problems related to communications and decision-making. During the stages of ideas exchange, definition of research lines and decision-making, a larger number of researchers may lead to unnecessary noise and hinder the work in progress. Likewise, smaller groups make communications more free-flowing and, consequently, result in more fruitful working processes.



Graph 2. Number of authors per article.

Source: Own elaboration

\section{Scientific journal host country}

As regards the journals publishing these works. The results of publications by country follow the authors' affiliation. The regions with the most cited authors are practically the same where the scientific journals with the highest 
number of citations are published. These regions include the most developed countries. The United States is in the first place, with $48 \%$ (no. = 120), followed by the United Kingdom with $30.1 \%($ no. $=77)$ and Netherlands, with $8.8 \%($ no. $=22)$ (figure 6$)$. It is noteworthy that two per cent (no. $=5$ ) out of the 250 articles analysed were published in online journals, which prevents the identification of the country of publication. Despite modern society displaying a digital matrix, education publications still follow traditional paths, with the most cited articles emerging from paper-based journals. While Turkey remains an emerging country, it hosts a surprising number of publications (no. $=12$ ), much higher than other countries further up in the development index, such as Australia (no. $=4$ ) or Spain (no. $=4$ ).

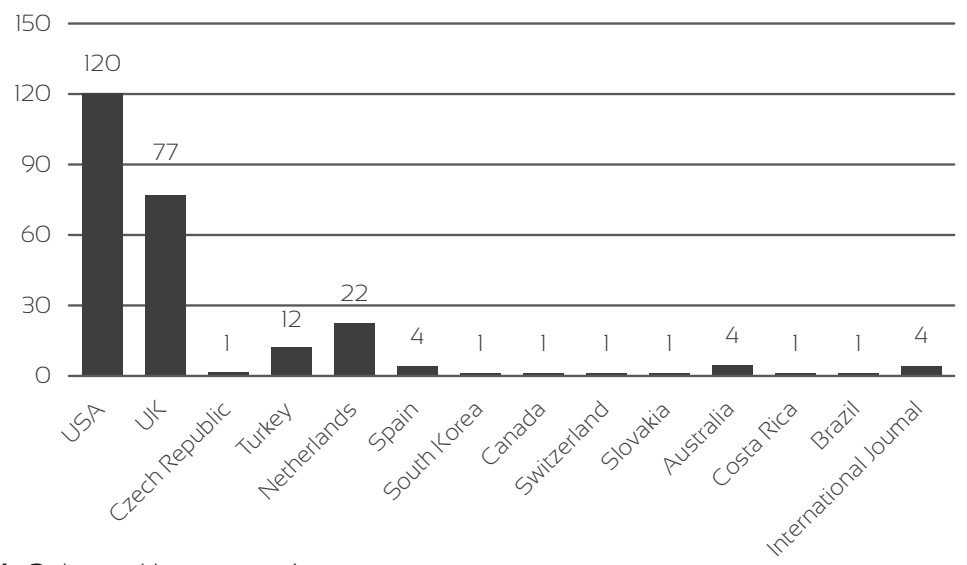

Graph 3. Journal host countries.

Source: Own elaboration

As for the year of publication of the article (graph 4), we may note the exponential growth in the last three years of the decade. In the first years, there was a period of stagnation before entering into a rise over the 2003-2005period. This difference might be explained for the two different periods in the definition of SL. At the turn of the century, sL gained new definitions, as evidenced in the works produced by authors such as Laugksch (2000), Miller (1998), Norris \& Phillips (2003), Rowan et al. (2002). This period of high intellectual production was followed by a calm time, during which some ideas were put into practice. Other constructs emerged in the following years, such as public awareness of science and, later on, public engagement with science, which came into more common usage at the expense of the concept of Scientific literacy (Davies et al., 2008; Einsiedel, 2007; Kerr et al., 2007). As the end of the decade drew in closer, the concept of SL was subject to evaluation and hence we may observe the corresponding rise in the number of articles published and, afterwrads, cited. 
90



Graph 4. Year of article publication.

Source: Own elaboration

\section{Dimensions of scientific literacy}

A qualitative analysis of the results obtained (Table 2) suggest the prevalence of some dimensions over others (Graph 5), with a particular emphasis on "Understanding the nature of science including the relationship with Culture", with $45 \%$ (no. = 150) of references, in comparison with "Appreciation and comfort with Science, including admiration and curiosity" with $16 \%$ (no. $=54)$ and "Capacity to use scientific knowledge for problem solving" with $15 \%$ (no. = 52).



A - Capacity to distinguish between Science and non-Science; B - Understanding of Science and its applications;

C - Understanding the nature of Science, including its relationship with Culture;

D - Appreciation and comfort with Science with Science, including admiration and curiosity; E - The skill to use scientific knowledge for problem solving; $\mathrm{F}$ - Understanding and valuing of S\&T and its interrelationship with society

Graph 5. Dimensions of scientific literacy.

Source: Own elaboration

The lack of criteria to distinguish between science and non-science or pseudo-science is central to the philosophy of science (Dupré, 1993; Laudan, 1996). The delimitation of these concepts is one of the dimensions that characterized the definition of science in the late twentieth century (Phillips \& Norris, 2002). It is also a feature of the public engagement with 
science approach, which keeps science and non-science distinct and extend the attempts to explore the interpenetration of science and society. During the transition to the new millennium there is an attempt to abandon this dichotomy between science and non-science advocating for an approximation between the two categories, which considers scientific knowledge and non-scientific knowledge as thoroughly interwoven, and these straddle the lines between pseudoscience and science (Levitt, 2002; Michael, 2002).

On the other hand, the boundary between these two categories "has been losing visibility in the philosophic circles even while science and technology have gained an unparalleled authority and the creationists and various groups of post-modernists have challenged this authority" (van Dijk, 2011). Towards the end of the decade, the approximation between science and non-science lost ground when various researchers came out in favour of the need for schools to teach the distinction between them(Akerson et al., 2010; Avraamidou \& Zembal-Saul, 2010). This need is a consequence of seeing SL as multidimensional and a composite of science concepts and ideas, the nature of science, and the interaction of science and society. These three dimensions are the highest level of SL and empower the citizens to think critically about the role of science in society (Murcia, 2009). Thus,

[...] science education should have the aspiration to include scientific literate competences that students need, to be able to live and participate with reasonable comfort, confidence, and responsibility in a society that is deeply influenced and shaped by the applications, ideas and values of science [...] (Klop et al., 2010).

These ideas are related to the dimension "science and its applications", according to which st commonly consists of the following scientific concepts and their applications in real-life contexts. That approach was controversial at the beginning of the century, when "[...] school science is almost exclusively concerned with basic or fundamental science [...] without thought of possible applications [...]" (Jenkins, 2002). As a result, "[...] many students are unable to participate in societal discussions about science and its related technological applications[...]" (Hofstein et al., 2011). During the decade, "the data suggest a shift from a relatively passive appreciation of science and the way it operates in society towards a concern for commitment to personal action as a critical feature of SL[...]" (Symington \& Tyler, 2007). Following this shift, technological applications of science were promoted as goals of the science curriculum, and the term SL was used to describe a broader study of science, especially in relation to its everyday applications (Bybee et al., 2009; Holbrook \& Rannikmae, 2009). According to this, "[...] scientifically literate individuals were able to effectively apply scientific knowledge and reasoning skills for problem-solving and decision-making in their personal, civic and professional lives [...]" (Murcia, 2008). In other words, they used science for learning, informing 
or contributing to problem-solving. Consequently, the "Capacity to apply scientific knowledge for problem solving" dimension gained importance at the end of the 1990s and its influence extended through the 2010s.

Modern society, with the new world order, very much based on global economy, needs its citizens to attain competences that enable them to rapidly summarise and evaluate new information, thinking critically and solving problems (Christensen, 2009; Fredricks et al., 2009; Holbrook \& Rannikmae, 2009; Sadler et al., 2006; Sülün et al., 2009). To achieve this goal, "[...] quantitative, communication, manual, and critical-response skills are essential for problem solving, but they are also part of what constitutes science literacy more generally [...]" (Spektor-Levy et al., 2009). Therefore, this intelligence, which deploys the intellectual tools of science, philosophy and the arts for the resolution of shared problems and the adoption of new solutions, becomes a competence to be developed by citizens which involves the logical and rational mechanisms inherent to problem-solving, as well as intuition, emotion and passion (Dani, 2009; Levinson, 2010; Witz \& Lee, 2009). This reflection does not only result in an intrinsic cognitive capacity, but also in the external conjuncture surrounding the individual (Klein \& Kirkpatrick, 2010). The association of SL with the resolution of problems has been present throughout the last four decades, not as a specific category but rather included in the practical literacy category.

The data collected reflect that the literature conceptualised three different-even if not mutually exclusive - categories for st: practical, civic and cultural (Shen, 1975). Practical literacy is defined as the capacity to hold scientific knowledge that may be deployed in the resolution of practical problems (Dillon, 2009; She, 1975). At the turn of the century, new challenges emerged in societies that called upon citizens to participate in decision-making, rendering the development of critical thinking about the role of science in society as a fundamental goal (Murcia, 2009). Science is being challenged to provide the knowledge to counter the devastating environmental problems that have been by-products of a century of war and economic conflict (Munby \& Shen, 2002). Out of this fact, arose the need to approximate the dialogue among individuals or groups of individuals and scientists (Levinson, 2010), as well as the idea that scientifically literate citizens can apply scientific knowledge and develop the scientific thinking necessary to resolve problems and make decisions in their personal, civic and professional lives (Darling-Hammond, 2000; Holbrook \& Rannikmae, 2009; Murcia, 2009). Literature defines a scientifically literate citizen as a person who has "[...] (an) understanding of the (a) basic concepts in science; (b) nature of science; (c) ethics that control scientists' work; (d) interrelationships of science and society; (e) interrelationships of science and the humanities and $(f)$ differences between science and technology [...]" (Murcia, 2009), including the capacity to apply scientific knowledge 
to problem-solving. This group includes those authors who associate sL with the "capacity to identify just which scientific knowledge is best applied to resolve problems" (Miller, 1998), to "usage of the process of science in the resolution of problems, decision making and promoting an understanding of the universe" (Sülün et al., 2009; Yuenyong \& Narjaikaew, 2009), and the "individuals who use knowledge for the taking of daily decisions, resolving problems, improving the quality of life and measuring the impact of science on themes such as morality or ethics" (Boujaude, 2002; Dani, 2009b; Hurd,1998; Holbrook \& Rannikmae, 1997). According to the data collected, this dimension of sL establishes a significant presence in the literature published throughout the first decade of this century. Accompanying this category, the focus turns to the role of education in the development of scientific thinking through science teaching. Schools should nurture the development of science-based competences and knowledge, those holding particular relevance at the social and professional levels, which enable the citizen to face personal challenges and take responsible socio-scientific decisions (Holbrook \& Rannikmae, 2009; Jimoyiannis, 2010). According to this, "[...] science educators have been encouraged to involve their students in ways that allow them to develop a keen appreciation of the places where science and technology articulate smoothly with one's experience of life [...]" (Roth \& Lee, 2003). Levinson goes substantially further to defend that "[...] if the teaching of the sciences serves democracy and is a source of democratic values, there should then emerge an interdisciplinary curriculum based on the resolution of problems that reflect the vast social and global themes [...]" (Levinson, 2010, p. ). This approach should promote the scientific proficiency to supply a shared laboratory of language, logic and competences for the resolution of problems in the classroom (Liu, 2009). This scientific proficiency can be translated into citizen participation in "socio-scientific issues that often involve complex problems, subject to scientific data or ethical considerations" (Dani, 2009). In addition to this perspective, there emerged a similar trend that seeks to involve students in the classroom in "debates that result in a better understanding of the vital role that science may perform in the resolution of important problems, without ever forgetting its limitations and uncertainties" (Christensen, 2009; Witz \& Lee, 2009). This idea correspondingly places the emphasis on "community participation" and the "collective praxis" in the taking of decisions on socio-scientific issues (McDonald \& Songer, 2008; Roth \& Lee, 2004b; Songer et al., 2003; Witz \& Lee, 2009).

Throughout this first decade, we find a very close relationship between science and society with a particular emphasis on the applications available to society. At this point, the highest level of SL requires an understanding of the interactions of science with society in which scientifically literate citizens will have the ability to think about the role science plays in society (Mur- 
cia, 2009). This relationship of proximity brought about the proposal of two complementary categories: "Understanding science and its applications" and "Understanding and appreciating S\&T and its interrelationship with society". The complementarity between these two dimensions requires closer scrutiny of science in terms of its production, interpretation, communication, and negotiation of scientific knowledge as a way of measuring the impact of science on society (Wolfensberger et al., 2010). Thus, there is an essential relationship between science and its technological application and society. It is necessary to implement science curricula that, in an initial phase, focus on knowledge about advanced scientific themes, and in a second phase, moves onto the applications of science (Marks \& Eilks, 2009; Rudolph, 2005; Wei, 2009). This assumption enables scientifically literate citizens to look more critically at the role of science in society (Murcia, 2009). In these terms, scientific education should hold the aspiration of developing the competencies enabling citizens to participate with reasonable comfort, trust and responsibility in a society profoundly shaped by scientific and technological applications (Fensham, 2009; Klop et al., 2010; Witz \& Lee, 2009).

Alongside this bidirectional relationship between science and society, another relationship began to take clear shape interconnecting SL with the nature of science when affirming that an understanding of nature played an important role in the development of the SL of citizens (Holbrook \& Rannikmae, 2009). Typically, the nature of science is defined as the way in which scientists attain knowledge (Schroeder et al., 2009). Literature include a category for the nature of science in their definitions of SL (Kim \& Roth, 2008; Laugksch, 2000; Wolff-Michael Roth, 2007; van Eijck \& Roth, 2010), given that it is not limited to holding scientific knowledge, but also implies knowledge about the nature of science (Baker et al., 2009; Murcia, 2009; Wolfensberger et al., 2010). As the nature of science represents a process involving different people (Baker et al., 2009), it is important that the understanding of science includes the understanding of the values and assumptions underlying scientific knowledge (Murcia, 2009) as well as the epistemology of science (Gyllenpalm et al., 2010; Holbrook \& Rannikmae, 2007). This may be expressed either through the nature of scientific knowledge or scientific endeavors (Baker et al., 2009; van Dijk \& Kattmann, 2007; Yore et al., 2007). Hence, different authors sustain that SL depends, at least in part, on the public understanding of the nature of science in the belief that it facilitates learning about scientific questions and their respective content (Dijk, 2011). In this context, knowledge about the nature of science proves essential to making informed decisions on socio-scientific issues and, in this way, becoming scientifically literate (Hand et al., 2010; Yore et al., 2003).

Indeed, st is placed on an appreciation of the nature of science, the development of personal attributes and the acquisition of socioscientific skills and values (Holbrook \& Rannikmae, 2009). It is generally agreed that

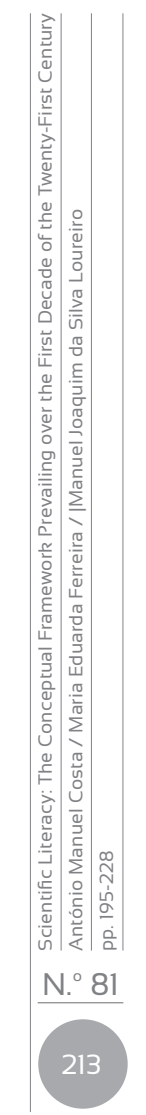


[...] a science-literate individual possesses a basic vocabulary of scientific concepts and terms, knowledge of the processes of science utilized to test our models for making sense of the world, and an appreciation of the effect of science and technology on society, to a degree sufficient to participate in dealing with the increasingly large number of science-and technology—laden public policy questions we face. (Roth \& Lee, 2009).

This framework for SL stems from the assumption that science serves as a driving force for democratic values and solidarity and that an awareness of science and the methods of science will lead to an appreciation of science among citizens (Deboer, 2000; Holbrook \& Rannikmae, 2009a).

Correspondingly, the literature puts forward a dimension to SL characterised by its "Appreciation and comfort with science, including admiration and curiosity" and based upon a change in behaviour towards science that embodies a transition from a passive attitude to a proactive involvement in the appreciation of scientific knowledge (Plakitsi, 2010; Symington \& Tytler, 2004). To put this attitudinal change into practice requires strategies to nurture creativity and motivation towards scientific themes, so as to attribute greater significance to the role played by s\&T in our culture (Osborne, 2007; Pedretti \& Nazir, 2010; Roth et al., 2009). In this sense, science and technology are the most significant determinants in our culture. "In order to decode our culture and enrich our participation-this includes protest and rejection - an appreciation/understanding of science is desirable" (Osborne et al., 2010). Coupled with this idea, "scientific literacy is placed on an appreciation of the nature of science, the development of personal attributes and the acquisition of socioscientific skills and values" (Holbrook \& Rannikmae, 2009).

The SL represented through these dimensions describes a matrix in which this construct is clearly identified as knowledge, but also coupled with thinking and acting (Bybee et al., 2009; Ford, 2006). Hence, this conceptual matrix gets deeply influenced by the trust and confidence and/ or the willingness of citizens to get involved with science-based contexts (Reveles et al., Rudolph, 2004). A scientifically literate citizen needs the capacity to use science as a tool for inquiring and discovering; apply science as a means of learning, getting informed and contributing to the resolution of problems; and critically reflecting on the usage and the role that science performs in society (Witz \& Lee, 2009). Optimising this assimilation, in turn, requires the development of these dimensions that occur in a sequential form, beginning with knowledge about science, advancing towards an understanding of the nature of science, which leads to an understanding of the relationship between science and society (Bybee \& McCrae, 2011; Ford, 2006; Murcia, 2009; Sülün et al., 2009). 









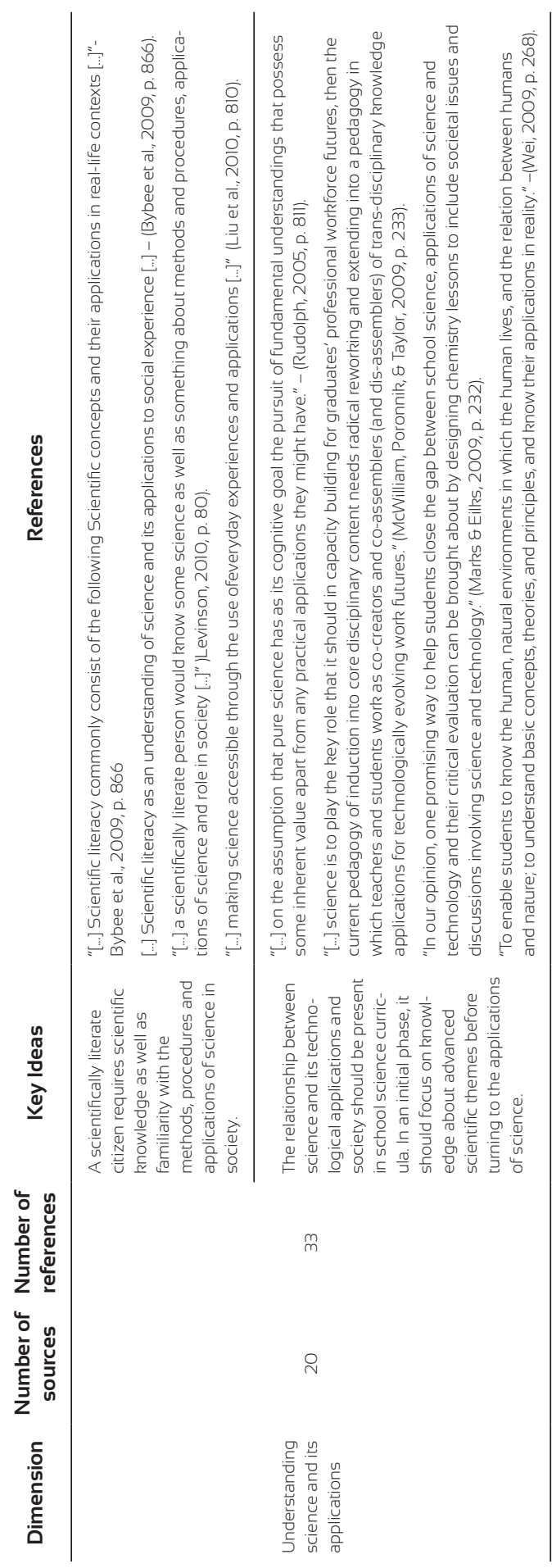














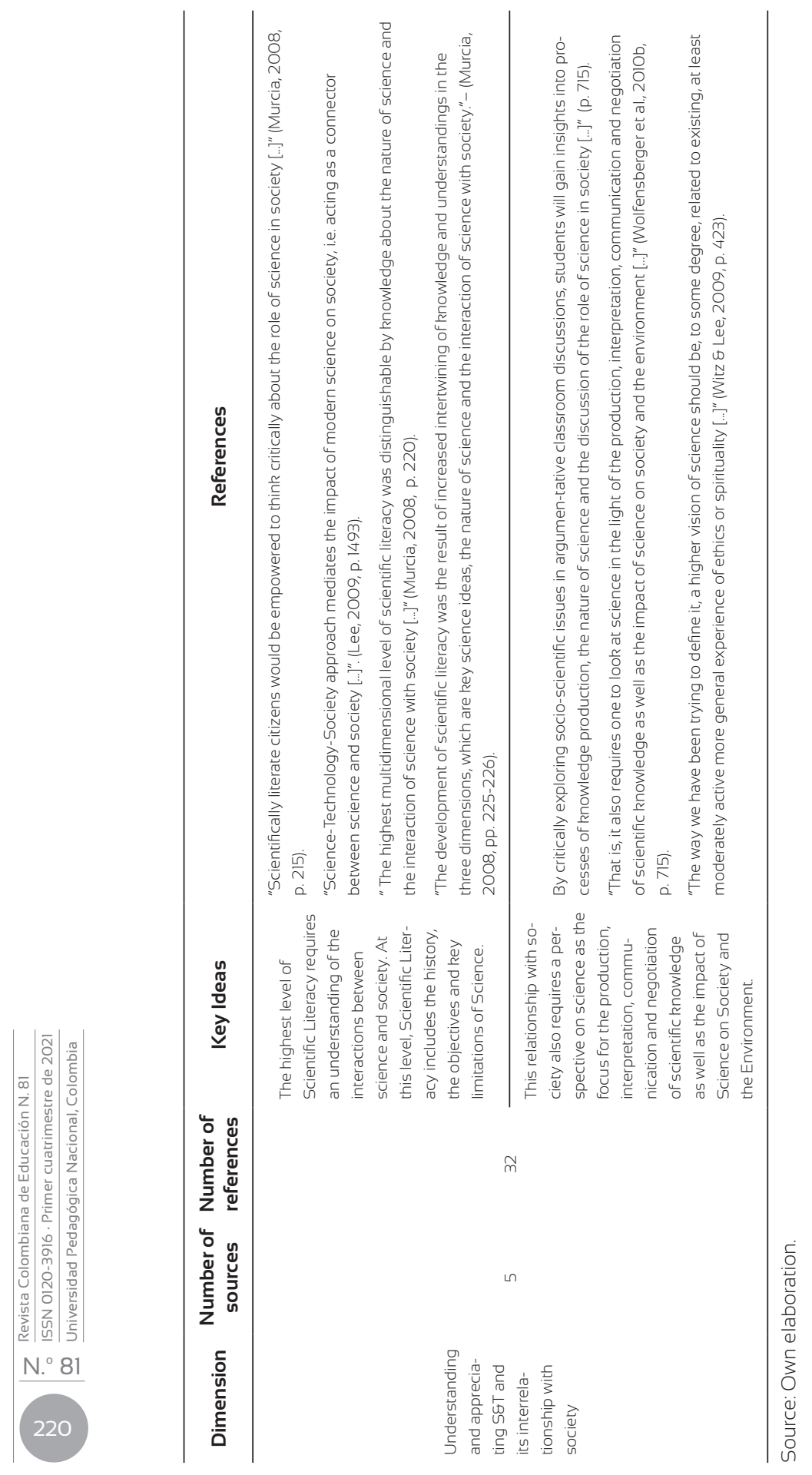




\section{Conclusion}

The literature review made it possible to observe a mutation in the definition of literacy throughout the first decade of the twenty-first century. This mutation in the scientific literacy construct accompanied all economic, social and cultural transformations that characterized the transition to the new millennium. Thus, rather than remaining static, scientific literacy acquired a deictic nature, as a construct that quickly changes its meaning when the context in which it operates changes.

Regarding the research questions, the authors drew the following conclusions.

What paradigm defined the sL existing in the early twenty-first century?

SL was clearly defined as a multidimensional construct, characterised by a composite of concepts and ideas about science, the nature of science and the integration of science into society. This conceptual framework that structures the new paradigm of SL arises from the interaction between the four following dimensions: concepts and ideas about science, the nature of science, interactions of science with society and the valuation and appreciation of science.

How did this construct evolve over the course of the first decade of the twenty-first century?

This polymorphic conception of SL stems from the bifurcation in a construct understood as fundamental, which enables citizens to understand the essential ideas of science and the relationships they maintain with the scientific method and the nature of science - and a construct perceived as a consequence that emphasizes the cognitive capacities and critical thinking as an instrument through which it becomes possible to inform other citizens and to participate in the public debate about science and technology more fully.

What model of sL characterises the relationship between science and society?

The interaction science-society, in what refers to the application of science on a daily basis, its implementation and its effects in social and natural environments, is one of the most evident mutations in the categorization of scientific literacy. There is a shift from the idea of learning of scientific contents to their application in society.

This new conceptual matrix suggests a change in the relatively passive form of appreciation of science and the way it operates in society towards a commitment to personal involvement with science. This change occurs 
in the way of understanding the nature of science, in the idea of analyzing how science behaves in society, in the way to interact with the scientific society, and in the utility of scientific knowledge throughout life.

The construction of the normative clarification in the context of SL led to upgrade research lines in science education inherent to this construct. In this context, stands out the idea of SL as a socio-scientific construct encompassed in a technical and scientific society where citizens are asked to be active and responsible members (Hofstein et al., 2010). This view emphasizes the contextualization of scientific themes combined with other dimensions-such as critical thinking, education for citizenship, and personal and collective responsibility of students-in order to provide them with sociocentric skills that enable them to be socially active citizens in the future (Wolfensberger et al., 2010).

A scientifically literate citizen recognises the accumulative, provisional and sceptical nature of science, the limitations to scientific inquiry, the need for the presence of sufficient evidence and consolidated knowledge for supporting or rejecting propositions, the impact of science and technology on the political, social and economic environment and as well as the influence of society on science and technology. This posits a challenge for the research lines in science education in favour of this scientific literacy construct.

\section{Future research}

Since scientific literacy is an emerging construct, a universal and unambiguous definition is a complicated task. There is a constant risk of being outdated as a result of the circumstances surrounding it. In this sense, and as future research, we will try to verify if this conceptual matrix has been transposed into education policies. For this purpose, we suggest to analyse public policy documents produced by different local, regional, national or transnational authorities.

\section{References}

Akerson, V. L., Buzzelli, C. A., Donnelly, L. A. (2010). On the nature of teaching nature of science: Preservice early childhood teachers' instruction in preschool and elementary settings. Journal of Research in Science Teaching, 47(2), 213-233. https://doi.org/10.1002/tea.20323

Avraamidou, L., \& Zembal-Saul, C. (2010). In search of well-started beginning science teachers: Insights from two first-year elementary teachers. Journal of Research in Science Teaching, 47(6), 661-686. https://doi.org/10.1002/tea.20359 
Baker, D. R., Lewis, E. B., Purzer, S., Watts, N. B., Perkins, G., Uysal, S., Wong, S., Beard, R. \& Lang, M. (2009). The Communication in Science Inquiry Project (CISIP): A project to enhance scientific literacy through the creation of science classroom discourse communities. International Journal of Environmental \& Science Education, 4(3), 259-274.

Bauer, M. W., Gaskell, G., Durant, J., Midden, C., Liakopoulous, M., \& Scholten, L. (2003). Two cultures of public understanding of science and technology in Europe. In M. Dierkes \& C. von Grote (Eds.), Between Understanding and Trust: The Public, Science and Technology (pp. 61-74). Taylor \& Francis Group.

Boujaoude, S. (2002). Balance of scientific literacy themes in science curricula: The case of Lebanon. International Journal of Science Education, 24(2), 139-156. https://doi.org/10.1080/09500690110066494

Bybee, R. (1997). Achieving Scientific Literacy: From Purposes to Practices Heinemann.

Bybee, R., \& McCrae, B. (2011). Scientific Literacy and Student Attitudes: Perspectives from PISA 2006 science. International Journal of Science Education, 33(1), 7-26. https://doi.org/10.1080/09500693.2010.51 8644

Bybee, R., McCrae, B., \& Laurie, R. (2009). PISA 2006: An assessment of scientific literacy. Journal of Research in Science Teaching, 46(8), 865-883. https://doi.org/10.1002/tea.20333

Caraça, J. (2001). Ciência. Quimera.

Choi, K., Lee, H., Shin, N., Kim, S.W., \& Krajcik, J. (2011). Re-conceptualization of scientific literacy in South Korea for the 21st century. Journal of Research in Science Teaching, 48(6), 670-697. https://doi. org/10.1002/tea.20424

Christensen, C. (2009). Risk and school science education. Studies in Science Education, 45(2), 205-223. https://doi.org/10.1080/ 03057260903142293

Dani, D. (2009). Scientific literacy and purposes for teaching science: A case study of Lebanese private school teachers. International Journal of Environmental \& Science Education, 4(3), 289-299. http://www. ijese.com/IJESE_v4n3_Special_Issue_Dani.pdf

Darling-Hammond, L. (2000). How Teacher Education Matters. Journal of Teacher Education, 51(3), 166-173. https://doi.org/10.1177/ 0022487100051003002

Davies, S., McCallie, E., Simonsson, E., Lehr, J. L., \& Duensing, S. (2008). Discussing dialogue: Perspectives on the value of science dialogue events that do not inform policy. Public Understanding of Science, 18(3), 338-353. https://doi.org/10.1177/0963662507079760 
Deboer, G. E. (1991). A History of Ideas in Science Education: Implications for Practice. Teachers College Press.

Deboer, G. E. (2000). Scientific Literacy : Another Look at Its Historical and Contemporary Meanings and Its Relationship to Science Education Reform. Journal of Research in Science Teaching, 37(6), 582-601.

Dijk, E. M., van. (2011). Portraying real science in science communication. Science Education, 95(6), 1086-1100. https://doi.org/10.1002/ sce. 20458

Dijk, E. M., van \& Kattmann, U. (2007). A research model for the study of science teachers' PCK and improving teacher education. Teaching and Teacher Education, 23(6), 885-897. https://doi.org/10.1016/j. tate.2006.05.002

Dillon, J. (2009). On scientific literacy and curriculum reform. International Journal of Environmental and Science Education, 4(3), 201-213. http:// www.ijese.com/IJESE_Volume4_Issue3_July_2009.pdf\#page $=11$

Dupré, J. A. (1993). The disorder of things: Metaphysical foundations of the disunity of science. Harvard University Press.

Eijck, M., van \& Roth, W. M. (2010). Theorizing scientific literacy in the wild. Educational Research Review, 5(2), 184-194. https://doi. org/10.1016/j.edurev.2010.03.002.

Einsiedel, E. (2007). Editorial: Of publics and science. Public Understanding of Science, 16(1), 5-6. https://doi.org/10.1177/0963662506071289

Fensham, P. J. (2009). Real world contexts in PISA science: Implications for context-based science education. Journal of Research in Science Teaching, 46(8), 884-896. https://doi.org/10.1002/tea.20334

Ford, D. J. (2006). Representations of science within children's trade books. Journal of Research in Science Teaching, 43(2), 214-235. https://doi.org/10.1002/tea.20095

Fredricks, J. A., Blumenfeld, P. C., \& Paris, A. H. (2009). School Engagement: Potential of the Concept, State of the Evidence, Review of Educational Research, 74(1), 59-109.

Gyllenpalm, J., Wickman, P., \& Holmgren, S. (2010). Teachers' Language on Scientific Inquiry: Methods of teaching or methods of inquiry? International Journal of Science Education, 32(9), 1151-1172. https:// doi.org/10.1080/09500690902977457

Hand, B., Yore, L. D., Jagger, S., \& Prain, V. (2010). Connecting research in science literacy and classroom practice: A review of science teaching journals in Australia, the UK and the United States, 1998-2008. Studies in Science Education, 46(1), 45-68. https://doi. org/10.1080/03057260903562342

Hofstein, A., Eilks, I., \& Bybee, R. (2011). Societal Issues and Their Importance for Contemporary Science Education-A Pedagogical 
Justification and the State-of-the-Art in Israel, Germany, and the USA. International Journal of Science and Mathematics Education, 9(6), 1459-1483. https://doi.org/10.1007/s10763-010-9273-9

Holbrook, J., \& Rannikmae, M. (2007). The nature of science education for enhancing scientific literacy. International Journal of Science Education, 29(11), 1347-1362. https://doi.org/10.1080/09500690601007549

Holbrook, J., \& Rannikmae, M. (2009). The meaning of scientific literacy. International Journal of Environmental and Science Education, 4(3), 275-288.

Hurd, P. D. (1998). Scientific literacy: New minds for a changing world. Science Education, 82(3), 407-416. https://doi.org/10.1002/(SICI)1098237x(199806)82:3<407::AID-SCE6>3.0.CO;2-G.

Irwin, A., \& Michael, M. (2003). Science, Social Theory and Public Knowledge. Open University Press.

Jenkins, E. W. (2002) Linking school science education with action. In W.-M. Roth and J. Désautels (Eds.), Science Education as/for Sociopolitical Action (pp. 17-34). Peter Lang.

Jimoyiannis, A. (2010). Designing and implementing an integrated technological pedagogical science knowledge framework for science teachers professional development. Computers \& Education, 55(3), 1259-1269. https://doi.org/10.1016/j.compedu.2010.05.022

Kerr, A., Cunningham-Burley, S., \& Tutton, R. (2007). Shifting subject positions: Experts and lay people in public dialogue. Social Studies of Science, 37(3), 385-411. https://doi.org/10.1177/03063127060 68492

Kim, M., \& Roth, W.-M. (2008). Rethinking the ethics of scientific knowledge: A case study of teaching the environment in science classrooms. Asia Pacific Education Review, 9(4), 516-528. https://doi.org/10.1007/ BF03025667

Klein, P. D., \& Kirkpatrick, L. C. (2010). Multimodal literacies in science: Currency, coherence and focus. Research in Science Education, 40(1), 87-92. https://doi.org/10.1007/s11165-009-9159-4

Klop, T., Severiens, S. E., Knippels, M. P. J., van Mil, M. H. W., \& Ten Dam, G. T. M. (2010). Effects of a Science Education Module on Attitudes towards Modern Biotechnology of Secondary School Students. International Journal of Science Education, 32(9), 1127-1150. https://doi. org/10.1080/09500690902943665

Laudan, L. (1996). The demise of the demarcation problem. In M. Ruse (Ed.), But is it science? The philosophical question in the creation/ evolution controversy (pp. 337-350). Prometheus Books.

Laugksch, R. (2000). Scientific literacy: A conceptual overview. Science Education, 84(1), 71-94. 
Levinson, R. (2010). Science education and democratic participation: An uneasy congruence? Studies in Science Education, 46(1), 69-119. https://doi.org/10.1080/03057260903562433

Levitt, K. E. (2002). An Analysis of Elementary Teachers' Beliefs Regarding the Teaching and Learning of Science. Science Education, 86(1), 1-22. https://doi.org/10.1002/sce.1042

Liu, O. L., Lee, H. S., \& Linn, M. C. (2010). An investigation of teacher impact on student inquiry science performance using a hierarchical linear model. Journal of Research in Science Teaching, 47(7), 807819. https://doi.org/10.1002/tea.20372

Liu, X. (2009). Beyond science literacy: Science and the public. International Journal of Environmental \& Science Education, 4(3), 301-311. http://www.ijese.com/JJESE_v4n3_Special_Issue_Lui.pdf

Marks, R., \& Eilks, I. (2009). Promoting scientific literacy using a sociocritical and problem-oriented approach to chemistry teaching: Concept, examples, experiences. International Journal of Environmental and Science Education, 4(3), 231-245.

McDonald, S., \& Songer, N. B. (2008). Enacting classroom inquiry: Theorizing teachers' conceptions of science teaching. Science Education, 92(6), 973-993. https://doi.org/10.1002/sce.20293

Michael, M. (2002). Comprehension, Apprehension, Prehension: Heterogeneity and the Public Understanding of Science. Science, Technology \& Human Values, 27(3), 357-378. https://doi.org/10.1177/016224390202700302

Miller, J. (1998). The measurement of civic scientific literacy. Public Understanding of Science, 7(3), 203-223. https://doi.org/10.1088/09636625/7/3/001

Miller, J. (2004). Public understanding of, and attitudes toward, scientific research:Whatweknowand whatweneed toknow. Public Understanding of Science, 13(3), 273-294. https://doi.org/10.1177/0963662504044908.

Miller, J., \& Pardo, R. (2003). Civic scientific literacy and attitude to science and technology: A comparative analysis of the European Union, the United States, Japan, and Canada. In M. Dierkes \& C. von Grote (Eds.), Between Understanding and Trust. The Public, Science, and Technology (pp. 81-130). Taylor \& Francis Group.

Murcia, K. (2009). Re-thinking the development of scientific literacy through a rope metaphor. Research in Science Education, 39(2), 215229. https://doi.org/10.1007/s11165-008-9081-1

Norris, S. P., \& Phillips, L. M. (2003). How literacy in its fundamental sense is central to scientific literacy. Science Education, 87(2), 224 240. https://doi.org/10.1002/sce.10066

Osborne, J. (2007). Science Education for the Twenty First Century, Eurasia Journal of Mathematics, Science \& Technology Education, 3(3), 173-184. 
Osborne, J., Simon, S., \& Collins, S. (2003). Attitudes towards science: A review of the literature and its implications. International Journal of Science Education, 25(9), 1049-1079. https://doi.org/10.1080/ 0950069032000032199

Osborne, J., Dillon, J. (2008). Science education in Europe: Critical reflections. The Nuffield Foundation.

Pedretti, E., \& Nazir, J. (2011). Currents in STSE education: Mapping a complex field, 40 years on. Science Education, 95(4), 601-626. https://doi. org/10.1002/sce.20435

Plakitsi, K. (2010). Collective curriculum design as a tool for rethinking scientific literacy. CulturalStudies of Science Education, 5(3), 577-590. https://doi.org/10.1007/s11422-010-9288-0

Roth, W. (2007). Toward a dialectical notion and praxis of scientific literacy. Journal of Curriculum Studies, 39(4), 377-398. https://doi. org/10.1080/00220270601032025

Roth, W., \& Lee, S. (2001). Rethinking scientific literacy: From science education as propaedeutic to participation in the community. https:// files.eric.ed.gov/fulltext/ED478153.pdf

Roth, W., \& Lee, S. (2004). Science education as/for participation in the community. Science Education, 88(2), 263-291. https://doi.org/10.1002/ sce. 10113

Roth, W., Lee, Y., \& Hsu, P. (2009). A tool for changing the world: Possibilities of cultural-historical activity theory to reinvigorate science education. Studies in Science Education, 45(2), 131-167. https://doi. org/10.1080/03057260903142269

Rowan, B., Correnti, R., \& Miller, R. J. (2002). What Large-Scale, Survey Research Tells Us About Teacher Effects On Student Achievement: Insights from the Prospects Study of Elementary Schools. CPRE Research Reports. https://repository.upenn.edu/cpre_researchreports/31

Rudolph, J. L. (2005). Inquiry, instrumentalism, and the public understanding of science. Science Education, 89(5), 803-821. https://doi. org/10.1002/sce.20071

Sadler, T. D., Amirshokoohi, A., Kazempour, M., \& Allspaw, K. M. (2006). Socioscience and ethics in science classrooms: Teacher perspectives and strategies. Journal of Research in Science Teaching, 43(4), 353376. https://doi.org/10.1002/tea.20142

Sadler, T. D., \& Zeidler, D. L. (2005). Patterns of informal reasoning in the context of socioscientific decision making. Journal of Research in Science Teaching, 42(1), 112-138. https://doi.org/10.1002/tea.20042

Schroeder, M., Mckeough, A., Graham, S., Stock, H., \& Bisanz, G. (2009). The contribution of trade books to early science literacy: In and out of school. Research in Science Education, 39(2), 231-250. https:// doi.org/10.1007/s11165-008-9082-0 
Songer, N. B., Lee, H. S., \& McDonald, S. (2003). Research Towards an Expanded Understanding of Inquiry Science Beyond One Idealized Standard. Science Education, 87(4), 490-516. https://doi.org/10.1002/ sce. 10085

Sülün, Y., Yurttas, G. D., \& Ekiz, S. O. (2009). Determination of science literacy levels of the classroom teachers (A case of Muggla city in Turkey). Procedia-Social and Behavioral Sciences, 1(1), 723-730. https://doi.org/10.1016/j.sbspro.2009.01.127

Symington, D., \& Tytler, R. (2004). Community leaders' views of the purposes of science in the compulsory years of schooling. International Journal of Science Education, 26(11), 1403-1418. https://doi.org/10. 1080/09500690410001673793

United Nations Educational, Scientific and Cultural Organization-Unesco. (2014). Adult and Youth Literacy. Institute for Statistics, (32), 1-4. http://www.uis.unesco.org/data/atlas-literacy/en

Wei, B. (2009). In search of meaningful integration: The experiences of developing integrated science curricula in junior secondary schools in China. International Journal of Science Education, 31(2), 259-277. https://doi.org/10.1080/09500690701687430

Witz, K. G., \& Lee, H. (2009). Science as an ideal: teachers' orientations to science and science education reform. Journal of Curriculum Studies, 41(3), 409-431. https://doi.org/10.1080/00220270802165640

Wolfensberger, B., Piniel, J., Canella, C., \& Kyburz-Graber, R. (2010). The challenge of involvement in reflective teaching: Three case studies from a teacher education project on conducting classroom discussions on socio-scientific issues. Teaching and Teacher Education, 26(3), 714-721. https://doi.org/10.1016/j.tate.2009.10.007

Yore, L. D., Gay, L., Hand, B. M., \& State, I. (2003). Examining the literacy component of science literacy: 25 years of language arts and science research. International Journal of Science Education, 25(6), 689-725. https://doi.org/10.1080/0950069032000076661

Yore, L. D., Pimm, D., \& Tuan, H.-L. (2007). The literacy component of mathematical and scientific literacy. International Journal of Science and Mathematics Education, 5(4), 559-589. https://doi.org/10.1007/ s10763-007-9089-4

Yuenyong, C., \& Narjaikaew, P. (2009). Scientific literacy and Thailand science education. International Journal of Environmental and Science Education, 4(3), 335-349.

Zeidler, D. L., Sadler, T. D., Simmons, M. L., \& Howes, E. V. (2005). Beyond STS: A research-based framework for socioscientific issues education. Science Education, 89(3), 357-377. https://doi.org/10.1002/sce.20048 